\title{
Infection Rate in Pediatric Compound Depressed Fractures Following Primary Replacement of Bone Fragments
}

\author{
AHMED KOHEIL, M.D. and WAEL M. NAZIM, M.D. \\ The Department of Neurosurgery, Faculty of Medicine, Beni Suef University
}

\begin{abstract}
Background: Compound depressed fractures is one of the common neurosurgical emergencies. Children presenting with this type of head injury, need careful and rapid decision to avoid lifelong morbidities as neurologic deficit. Surgery, according to most authors, is the gold standard in management, however, post-operative wound infection remains a serious complication.
\end{abstract}

Aim of Study: The purpose of this study was to identify frequency of infection in pediatric population with compound depressed skull fractures managed by placement of bone chips after cleaning with betadine and antibiotic.

Patients and Methods: This study included 41 patients aged less than 16 years. All patients had Glasgow Coma Scale of 15. Surgery was done within 24 hours following trauma. Full clinical examination, motor power assessment was and brain CT scan was done to all patients. Bone fragments were placed after cleaning with betadine, saline and gentamicin antibiotic. Patients were assessed for wound infection following surgery for the next 3 month.

Results: Patients' mean age was 7.8 years, $80.5 \%$ of them were males. The site of the compound depressed fracture was left frontal in $36.6 \%$ of cases. Fractures were complicated by dural tear in $43.9 \%$ of cases. Fall from height was the commonest mode of trauma in $41.5 \%$ of patients. Infection rate was $7.3 \%$ of the cases.

Conclusion: The risk of infection in pediatric compound depressed fractures managed by placement of bone chips after cleaning with betadine and saline with gentamicin antibiotic in the first 24 hours following surgery was low.

Key Words: Compound depressed fracture - Infection-Bone replacement.

\section{Introduction}

COMPOUND depressed fracture is a common presentations in pediatric patients, it could be

Correspondence to: Dr. Ahmed Koheil, The Department of Neurosurgery, Faculty of Medicine, Beni Suef University complicated by lifelong morbidity as epilepsy and neurologic deficit [1]. Falling from height is the commonest cause in pediatrics [2]. Management includes cranioplasty with or without titanium mesh, few cases of simple low depth fractures can be managed by suturing without cranioplasty $[\mathbf{3 , 4 ]}$.

Cranioplasty relieves compression on the brain matteranddecreases risk of infection [5,6]. Most surgeonsconsider surgerya safe procedure that is associated with no or low infection risk as low as 1 . $6 \%$ in most cases $[7,8]$.

\section{Patients and Methods}

In this study, the medical records of patients aged less than 16 years who presented with compound depressed fractures and were admitted to Neurosurgery Department in the period from January 2016 to December 2018 were retrospectively reviewed.

Inclusion criteria were: Non missile injuries, isolated head trauma, having Glasgow Coma Scale of 15 and presentation within 24 hours after trauma. This study excluded compound depressed fractures over the air sinuses and patients having associated intracranial pathology.

Forty one patients with compound depressed fractures fulfilled the inclusion criteria of the study.

Full neurologic examination was done, including motor and sensory examination, coordination and conscious level assessment. Radiological assessment was done including initial pre-operative computed tomography scan CT brain and a followup CT brain post-operative. Post-operative CT scanning was done to make sure that bone is in normal position and no cosmetic disfigurement. 
Prophylactic antibiotics were given pre and postoperative.

Surgery was scheduled in the first 24 hours of trauma, bone fragments were washed using betadine and saline with gentamycin antibiotic for a period of 5 minutes. Patients were monitored in the next three month post-operative for signs of infection as fever, pus around wound edges, elevated Creactive protein CRP and lymphocytosis.

Data were statistically described in terms of mean \pm standard deviation ( \pm SD), and range, or frequencies (number of cases) and percentages when appropriate. Comparison between pre and post-operative values was done using paired $t$-test. For comparing categorical data, Chi-square $\left(\chi^{2}\right)$ test was performed. $p$-values less than 0.05 was considered statistically significant. All statistical calculations were done using computer program IBM SPSS (Statistical Package for the Social Science; IBM Corp, Armonk, NY, USA) release 22 for Microsoft Windows.

\section{Results}

Patients' age ranged from one to 14 years with a mean of 7.8 years. Thirty three $(80.5 \%)$ males and $8(19.5 \%)$ females.

Table (1) shows site of compound depressed fracture. Mode of trauma was fall from height in $41.5 \%$, motor car accidents in $31.7 \%$ and being hit with a heavy objects in $26.8 \%$. Fractures were complicated by dural tear in $43.9 \%$ of cases.

Table (1): Site of compound depressed fracture.

\begin{tabular}{lll}
\hline Site & $\mathrm{n}=41$ & Percent \\
\hline Lt frontal & 15 & 36.6 \\
Lt occipital & 1 & 2.4 \\
Lt parietal & 7 & 17.1 \\
Lt tempro parietal & 1 & 2.4 \\
Parital & 1 & 2.4 \\
Rt frontal & 10 & 24.4 \\
Rt occipital & 2 & 4.9 \\
Rt parietal & 3 & 7.3 \\
Rt parital & 1 & 2.4 \\
\hline
\end{tabular}

$\mathrm{N}$ : Number of cases.

Infection was observed in $7.3 \%$ of studied patients. Infection was diagnosed in the setting of clinical observation of superficial wound infection and elevated CRP. Table (2) shows correlation between infection and dural tear. No correlation was found between post-operative infection and the presence ofdural tear.
Table (2): Correlation between infection and dural tear using Chi square test.

\begin{tabular}{llll}
\hline & \multicolumn{2}{c}{ Dural tear } & \multirow{2}{*}{$p$-value } \\
\cline { 2 - 3 } & No & Yes & \\
\hline No infection: & & & \multirow{2}{*}{0.652} \\
Number of cases & 21 & 17 & \\
$\%$ within infection & $55.3 \%$ & $44.7 \%$ & \\
$\%$ within dural tear & $91.3 \%$ & $94.4 \%$ & \\
Infection: & & & \\
Number of cases & 2 & 1 & \\
$\%$ within infection & $66.7 \%$ & $33.3 \%$ & \\
$\%$ within dural tear & $8.7 \%$ & $5.6 \%$ & \\
\hline
\end{tabular}

\section{Discussion}

In this study, 41 pediatric patients with compound depressed skull fractures were retrospectively studied. Surgery was scheduled in the first 24 hours of trauma with placement of bone fragments after cleaning. These patients were assessed for wound infection following surgery for the next 3 month. Infection occurred in $7.3 \%$ of patients.

Absence of control group is considered a limitation in the study, this can be explained by ethical reasons as the hospital policy considers early surgery the treatment of choice in all patients apart from few cases who presented late to the hospital or had an associated injury which caused delay in surgery. Focusing on pediatric patients is considered a strength point of the current study.

Patients with poor general condition and unstable vital signs were excluded to avoid biased results as those patients exhibit higher rates of infection due to nosocomial causes. The reason for the exclusion criteria in this study was to focus on infection rate directly caused by compound depressed fractures and not mixed with other probable causes like disturbed conscious level or prolonged intensive care unit ICU admission or intracranial hemorrhages that may require operations or procedures that may increase risk of infection. And also to focus on pediatric age group older patients were excluded.

Multiple studies have reached the conclusion that primary bone fragment replacement is a good option with low risk of infection. Wylen et al., stated that in primary replacement of bone fragments no infection was reported [4]. Kadir oktay et al., had an infection rate of $2.5 \%$ among his patients with primary bone replacement [5]. Maqsood Akram et al., had no infection in his study alcn [11 
A higher incidence of infection was noted by Jennet and Miller, 10.6\% [3].

Reconstruction by titanium mesh was recommended by Marbacher et al., [9,12], also others preferred dissociate bone cranioplasty over lever up cranioplasty due to better plasticity and safety [12].

The use of titanium clamps in comminuted compound depressed fractures and early surgery was also considered safe and not associated by infection [13].

An old report in 1989 discussing management ofpatients between 1972 and 1984 was against surgery as a standard choice, this has probably changed due to advances in surgical skills, techniques and huge radiological advances in the past 30 years [14].

In concordance with the current study, there has been an agreement on safety and low infection risk of cranioplasty with bone replacement for the management of compound depressed fractures [11$13,15,16$.

The frequency of infection was higher in this study $7.3 \%$ compared to others, this might be explained by the fact that the hospital from which data was collected is serving several rural areas in its geographic distribution.

Prospective randomized controlled studies with more patients with primary bone replacement in compound depressed fractures are needed to reacha protocol that is beneficial for the patients.

\section{Conclusion:}

The risk of infection in pediatric compound depressed fractures with placement of bone chips after in the first 24 hours following surgery was very low $7.3 \%$.

Compliance with ethical standards: The study conformed to the provisions of the Declaration of Helsinki.

Funding: No funding was received for this research.

Conflict of interest: Authors certify that they have no affiliations with or involvement in any organization or entity with any financial interest.

\section{References}

1- AKRAM M., AHMED I., QUERESHI N.A., BHATTI S. H. and ISHFAQ A.: Outcome of primary bone fragment replacement in compound depressed skull fractures. J. Coll physicians Surg. Pak., 17 (12): 744-8, 2007.
2- MOHAMED ABDELRAHMAN ABDEL FTAH: Management of bone fragments in nonmissile compound depressed skull fractures. Acta Neurochir., 158: 2341-5, 2016.

3- JENNET B. and MILLER J.D.: Infections after depressed fracture of skull. Implications for management of nonmissile injuries. J. Neurosurg., 36 (3): 333-9, 1972.

4- WYLEN E.L., WILLIS B.K. and NANDA A.: Infection rate with replacement of bone fragment in compound depressed skull fractures. Surg. Neurol., 51 (4): 452-7, 1999.

5- KADIR OKTAY, EBRU GUZEL, EMRE UNAL, TEVFIK YILMAZ and ALI IHSAN OCTEN: Outcome of primary bone fragment replacement in pediatric patients with depressed skull fractures. Pediatr. Neurosurg., 54 (1): 2835,2019 .

6- CHRISTOPHER M. BONFIELD, SANJAY NARAN, OLUWASEUN A. ADETAYO, IAN F. POLLACK and JOSEPH E. LOSEE: Pediatric skull fractures: The need for surgical intervention, characteristics, complications and outcome. J. Neurosurg. Pediatr., 14 (2): 205-11, 2014.

7- A. ADELOYE and M.T. SHOKUNBI: Immediate bone replacement in compound depressed skull fractures. Cent. Afr. J. Med., 39 (4): 70-3, 1993.

8- M.O.N. NNADI, O.B. BANKOLE and S.O. ARIGBABU: Outcome of surgically treated non missile traumatic skull fracture. Niger. Postgrad. Med. J., 21 (4): 311-4, 2014.

9- MARBACHER, SERGE, M.D., M.Sc.; ANDRES ROBERT H., M.D.; FATHI ALI-REZA, M.D. and FANDINO JAVIER, M.D.: Primary Reconstruction of Open Depressed Skull Fractures With Titanium Mesh. Journal of Craniofacial Surgery, 19 (2): 490-5, 2008.

10- NAYAK P.K. and MAHAPATRA A.K.: Primary reconstruction of depressed skull fracture-the changing scenario. IJNT, 5: 35-38, 2007.

11- SHAO XUEFEI, WANG QIFU, SHEN JUN, LIU JIAQIANG, CHEN SANSONG, M.D. and JIANG XIAOCHUN: Treatment of Traumatic Depressed Compound Skull Fractures, Journal of Craniofacial Surgery, 30 (7): 2239-44, 2019.

12- WAN YINGFENG, MMed; LI XINWEI, M.D.; QIAN CONG, M.D.; XUE ZHAOLIANG, MMed; YANG SHUXU and WANG YIRONG: The Comparison Between Dissociate Bone Flap Cranioplasty and Traditional Cranioplasty in the Treatment of Depressed Skull Fractures. Journal of Craniofacial Surgery, 24 (2): 589-91, 2013.

13- LI XINWEI, QIAN CHONG, YANG SHUXU, CHEN YILI, SUN WEIJUN and WANG YIRONG: Cranial Reconstruction With Titanium Clamps in Frontal Comminuted Depressed Skull Fractures, Journal of Craniofacial Surgery, 24 (1): 247-9, 2013.

14- VAN DEN HEEVER, C. MAURITZ and DAVID J. VAN DER MERWE: Management of depressed skull fractures. Journal of Neurosurgery, 71 (2): 186-90, 1989.

15- BULLOCK M.R., CHESNUT R., GHAJAR J., GORDON D., HARTL R., NEWELL D.W., SERVADEI F., WALTERS B.C. and WILBERGER J.: Surgical Management of Traumatic Brain Injury. Surgical management of depressed cranial fractures. Neurosurgery, 58 (3): 56-60, 2006. 


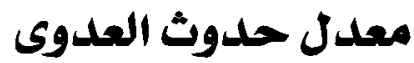 \\ بعد جراحة الكسر المضاعف المنضفط فلى العلى الآطفال}

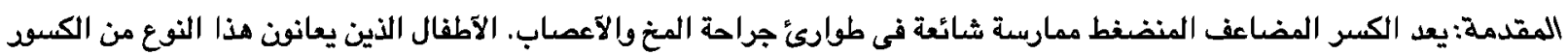

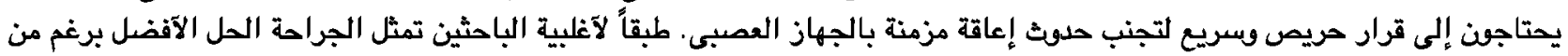
حدوث العدىى كآحد مضاعفات الجراحة.

الهدف من البحث: التعرف على معدل حدوث العدوى فى الآطفال بعد جراحة الكسر المضاعف المنضفط والتى تشمل تنظيف شظايا العظام بيتادين ومضاد حيوى ثم إعادتها.

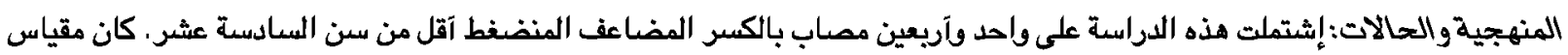

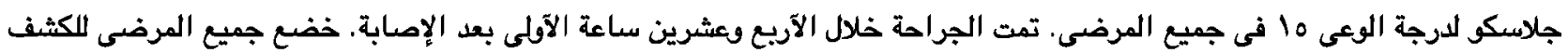

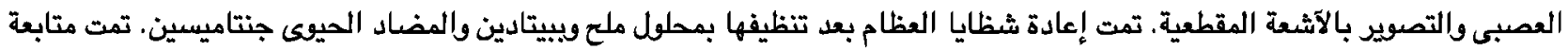

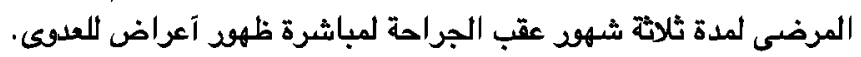

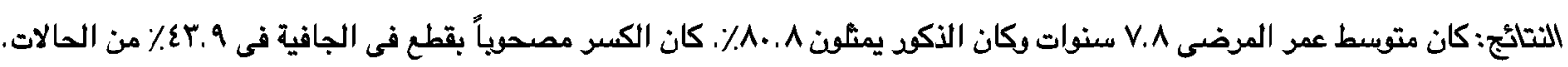

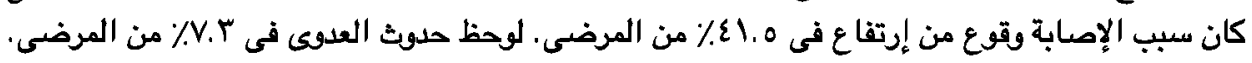
الإستستاج:معدل حدوث العدىى بعد جراحة الكسر المركب المنضغط فى الآطفال تعتبر منخفضة. 